\title{
Government Policy In Coastal Management And Small Island Muna Regency, Indonesia
}

\author{
La Ode Restele ${ }^{1}$, La Ode Sahaba ${ }^{2}$, La Ode Muh Munadi*3 \\ ${ }^{1}$ Faculty of Education, Halu Oleo University, Kampus Hijau Bumi \\ Tridharma, Anduonohu, Kendari, Southeast Sulawesi \\ ${ }^{2}$ Faculty of Animal Science, Halu Oleo University, Kampus Hijau Bumi \\ Tridharma, Anduonohu, Kendari, Southeast Sulawesi. \\ ${ }^{*}$ Corresponding author: \\ Email: $\underline{\text { lmmunadi@yahoo.com }}$
}

\begin{abstract}
.
Improving the management of coastal areas and small islands needs to have the support of the State of Indonesia as the world's maritime axis area because it has abundant fisheries and marine wealth. The study was conducted in Muna Regency in April-June 2021 with the determination of the location of purposive sampling in the archipelago. Research uses qualitative and quantitative approaches with data collection methods including observations, interviews and document studies using SWOT analysis. The results of the study showed the Muna Regency government in improving the management of coastal areas and small islands provides convenience and support both namely financial access, coaching, counseling and assistance for fishing communities.
\end{abstract}

Keywords: Coastal Management, Small Island, Muna.

\section{INTRODUCTION}

Understanding the seaside zone until now has not had a more structured understanding. An understanding of the coastal zone is the middle zone between land and ocean $[1,2]$. The beach area there are two types, namely, the boundary that corresponds to the coastline and the boundary opposite the coastline $[3,4]$. Natural damage that occurs both in the marine environment and different biological systems is triggered by several components including financial, strategic and damage to the value of biological systems of marine assets [5]. Territorial or territorial development is a coordinated program that takes into account its commitment to the progress of a space or region [6]. The potential for strategic marine wealth provides benefits and possibilities for Indonesia to take advantage of the rules of international maritime conventions [7]. Coastal areas are a meeting between land and sea including some dry or submerged land that is influenced by marine characteristics such as tides, sea breezes, and saltwater seepage [8,9].The development potential of coastal and marine areas is divided into three parts, namely, recoverable natural resources, irreversible natural resources, and environmental services [10,11]. Improvement of coastal areas and small islands also requires the role of the government in improving the regional economy such as providing motivators, regulating provincial financial development, and preparing regulations and administration for superior business progress $[12,13]$. 
The waterfront zone has high potential, this possibility includes sustainable assets including mangroves, coral reefs, seagrass meadows, and marine fishery assets, mineral and topographic assets, natural administration, travel industry, transportation, and fuel sources $[14,15]$.

The progress and improvement of coastal areas requires consideration so as not to damage the waterfront zone, for example freeing up shrimp development land by cutting down mangrove forests [16].Coastal areas are the confluence between land and inundated oceans, influenced by marine characteristics such as tides, sea breezes, and saltwater catchment [17]. Coastal areas include parts of the ocean that are still affected by natural processes that occur on land such as sedimentation and freshwater flows, as well as those caused by human activities on land such as deforestation and pollution [18]. Macro-management of natural resources becomes the authority of the central government and it is explained that the natural resources contained therein are managed by the state and aimed at the welfare of the people [19]. Damage to the mangrove environment in coastal areas has caused physical and natural damage to the coast resulting in reduced coastal conveyor limits as a result of damaging the suitability of the waterfront area and the monetary resilience of the coastal front network [20,21]. Socially and ecologically the irregularity between the level of asset use in the waterfront area and the losses incurred by excessive fishing conditions, resulting in the beach being damaged and it is an issue of water level improvement [22, 23].The coastal area of Muna Regency is a strategic area that is growing rapidly as a potential buffer area in economic development by utilizing the potential of existing coastal resources.

The problem of becoming an important issue arises today is the limited data on potential and coastal development in Muna Regency comprehensively. So, these stakeholders take decisions in order to develop their potential does not have a good development direction. Efforts to formulate the development of coastal areas are to carry out inventory and mapping of the potential of coastal natural resources, so that accurate data is available for the planning of the development of coastal areas of Muna Regency.The development of coastal areas in Muna Regency has various problems. However, local governments have taken various policies in addressing these problems, including the community playing a role in improving and improving the quality of the coastal environment. This study analyzed how much influence the government and the role of the community on the management of coastal areas and small islands with the aim of identifying the existing conditions of the region, the role of the government and the planning of coastal area development strategies in Muna Regency.

\section{METHODS}

The study was conducted in Muna Regency in April-June 2021 with survey methods and location determination by purposive sampling. The number of respondents was 250 people based on coastal and island criteria, based on the lowest, 
medium and high population density. The results of clustering the area resulted in research locations in sub-districts located in coastal areas are Kabangka, Kabawo, Parigi, Marobo, Towea, Napabalano, Lasalepa, Batalaiwaru, Katobu, Duruka, Lohia, Tongkuno, Maligano, and Batukara districts. Meanwhile, subdistricts in small island areas are South Wakorumba Subdistrict, Pasir Putih Subdistrict and Pasi Kolaga Subdistrict. Data collection is carried out through observation techniques, interviews, and document studies aimed at knowing the potential and constraints of research areas in relation to the government in the development of coastal areas. Furthermore, the data obtained is analyzed descriptively to describe the phenomenon that occurs during research in the form of Strengthness, Weakness, Opportunities, Threatness (SWOT).

\section{RESULT AND DISCUSSION}

\subsection{Muna Regency Coastal Area Development Strategy}

Muna regency has trade and service potential along the coast, this shows that the coastal area as an economic center. Subdistricts located in coastal areas and in direct contact with the sea are Kabangka, Kabawo, Parigi, Marobo, Towea, Napabalano, Lasalepa, Batalaiwaru, Katobu, Duruka, Lohia, Tongkuno, Maligano, and Batukara Districts. While for sub-districts in small island areas in Muna Regency, among others are South Wakorumba District, Pasir Putih District and Pasi Kolaga District. The strategy of fisheries sector development in coastal areas in Muna Regency the results of SWOT analysis show that.

\section{Strength Factor}

1. Muna Regency has a coastline of $55.92 \mathrm{~km}^{2}$

2. Land use tends to have higher economic value.

3. Have good ecological potential

4. As a buffer area of coastal cities between Bau-Bau City and Kendari City

5. Fishery commodities are available both fishing, seaweed cultivation, marine cultivation, ponds and freshwater ponds.

\section{Weakness Factor}

1. Procurement and distribution of fishery and aquaculture production facilities

a. Capital assistance has not been evenly distributed to fishermen

b. Coaching, counseling and research are rarely done.

c. There are no coordinated local institutions/organizations.

2. Main production activities of fishing and ponds
a. Low seed quality
b.People's knowledge and skills in the field of marketing are still low.
c. Local institutions that have not run optimally
d. Access to technology has not yet developed
e. Local institutions are still running independently.

3. Processing Activities (Agroindustry) 

a. Lack of innovation in processing activities
b.Low public interest in processing activities
c. Lack of coaching and counseling activities related to processing.
d.Lack of repair services damage to processing industry equipment

4. Marketing Activities

a. The results of the pond have never been marketed.

b.Lack of government support both in terms of policy, capital, guidance and counseling on marketing activities.

\section{Opportunity Factor}

1. Availability of budget facilities and infrastructure for the development of coastal and marine areas

2. There is a fish hatchery effort

3. The community is ready to develop seeding business

4. Access to the fishing business market in good condition

5. Ease of getting fishing facilities

6. Have local institutions that regulate fisheries business actors

7. Have market trading facilities and are ready to develop fishing agroindustry activities.

\section{Threatness Factor}

1. Utilization of coastal areas as centers of economic growth causes loss of natural function

2. Land use can threaten the sustainability of marine ecosystems in the form of ecology

3. Environmental pollution in coastal areas

4. The younger generation rarely attends school in the field of fisheries

The method of formulating strategies used to maximize strength to reduce the significant impact of barriers to the development of fisheries in coastal areas is directed at the fisheries agribusiness area which aims to have a major economic function, namely with a marine-based fisheries agribusiness approach with the principles of integration, efficiency, quality and acceleration and education of storage, processing, packaging and marketing techniques of products.Related to the strategy, agribusiness activities with certain conditions so that each sub-district that is in direct contact with the sea can position itself as an upstream and aquaculture sector. This is because, Having Human Resources with technical ability to manage well in the fisheries sector, Having local groups or institutions to coordinate activities in the upstream sector, Having access to financing, staffing, management and development, The availability of supporting institutions to provide counseling and training through in creating new innovations, The availability of research facilities for the development of Indoor Hatchery for Domestic Scale (HSRT) technology.

The development of coastal areas has the primacy of the cultivation sector because it has a strategic geographical location and meets the requirements of the 
development of superior aquaculture marketing products, adequate environmental conditions and vast cultivation land, Has superior commodities and high economic value, Has a local institution tasked with coordinating and responsible for fishing and aquaculture activities, Has supporting infrastructure such as water availability, wastewater networks, clean water networks, power grids, and telecommunications networks, and spatially, coastal areas can be developed into potential areas to be used as Minapolitan-based fisheries management centers in Muna Regency.

The procurement and distribution components of fishery business production facilities have not been properly maximized. This activity can be done in the capital city of Muna Regency (main service), Kabangka District, Kabawo, Parigi, Marobo, Towea, Napabalano, Lasalepa, Batalaiwaru, Katobu, Duruka, Lohia, Tongkuno, Maligano, Batukara, South Wakorumba, Pasir Putih and Pasi Kolaga District. The district will complement each other, making it easier for fishermen to get equipment at work. But there are also shortcomings in aspects of institutional support such as capital assistance, equipment, coaching and training and government policies. Efforts and full support from the government to support the procurement and distribution of fishery production facilities, because this activity component is the input component of production activities. The main production activities component of fisheries business, is divided into two, namely: fishing and aquaculture.

\subsection{Driving Aspects of Muna Regency Coastal Area Development}

The strategy of coastal development is to utilize the potential of the region in overcoming several problems in coastal areas, namely, conducting periodic inspections and sanctions against communities, industries, business actors that damage the coastal environment, optimizing agricultural vocational schools related to fisheries and youth approaches by cooperating with youth organizations involved in fisheries organizations. Explanation of the forces and threats related to coastal areas carried out strategic steps, namely;

1. Procurement of garbage filtering to the beach so as not to damage the marine ecosystem

2. Have a development laboratory as an effort to improve technology

3. Organizing vocational schools related to fisheries supports fisheries development in Muna Regency.

4. Commitment of business actors in the efforts of existence and improvement of aquaculture and aquaculture activities.

The formulation of the strategy of the four points is explained in its entirety, in the form of a combination of several processes. Processing can also be modified as needed or financial factors.

1. Primary Care

a. Filtering, sewage flowing through the sewer is filtered using filtering methods to remove large solids from wastewater. 
b. Pretreatment, the filtered waste is streamed into the tub to separate the sand and suspended solid particles that are relatively large by slowing the flow of waste so that sand particles fall to the bottom of the tank.

c. Deposition, after going through the processing stage of liquid waste is flowed to the reservoir by sedimentation method. These particles form a sludge which is then processed wastewater deposition or floation.

d. Floation, This method is effective at removing pollutants in the form of oil or fat using a tool that produces small air bubbles ( $\pm 30-120$ microns).

\section{Secondary Care}

Secondary processing is a biological process, involving microorganisms that can decompose organic matter. Commonly used microorganisms are aerobic bacteria. There are three commonly used biological processing methods: the trickling filter method, the active sludge method, and the pool treatment method.

\section{Tertiary Care}

Tertiary processing is carried out if primary and secondary treatment still contains certain substances in liquid waste that can harm the environment or society. Tertiary treatment is special, meaning that this treatment is adjusted to the content of waste substances in liquid waste/wastewater. In general, substances that cannot be eliminated entirely through primary or secondary processes are inorganic substances, such as nitrates, phosphates, and salts.

\section{Disinfection}

Disinfection or killing of germs aims to kill or reduce pathogenic microorganisms present in wastewater. Things to note at this stage are the toxicity of the material, the required contact time, the effectiveness of the material, the level of dosage used, should not be toxic for humans and animals, resistant to water and have low cost properties.

\subsection{Factors for the Development of Coastal Areas of Muna Regency}

Coastal development minimizes obstacles with opportunities in coastal areas with the target of the government, business people, fishermen and the surrounding community with the commitment of local governments in providing ease and support for financial access and assistance to fishing communities. Improving development, counseling for business actors and the community needs to be done in carrying out the strategy is:

1. Procurement and distribution of Fisheries Production Facilities.

Government

a. Distribution of capital assistance from the government to business actors

b. Create government policies/regulations in support of procurement and distribution activities of production facilities

c. Improving development, counseling for business people and surrounding communities

Businessman 
a. Establish local institutions/organizations to coordinate procurement and distribution activities of production facilities

b. Invite the community to contribute to procurement and distribution activities.

Local community

a. Play an active role in the procurement and distribution of fishery production facilities

b. Primary production activities of fishing and ponds

2. Processing Activities (Agroindustry)

Government

a. Distribution of tools for production activities

b. Increase the role and supervision of policies/regulations that have been established in fishing and aquaculture activities

c. Improve access to technology for coastal communities by building mini laboratories as research sites

d. Provide counseling, guidance and assistance to the production process that takes place periodically

e. Improving the quality and service of supporting infrastructure such as highways, ports and TPI

Businessman

a. Facilitate capital access for fishermen

b. Active in local institutional organizations that have been established to maintain consistency in developing production activities in coastal areas

c. Play an active role in primary production activities

3. Processing Activities

Government

a. Increase outreach, training and coaching for businesses and local communities

b. Increase capital assistance and equipment for processing activities

Businessman

a. Opening up jobs for the community

Local community

a. Innovate in the manufacture of processed food made from fish

b. Willing to be involved in processing activities

4. Marketing Activities

Government

a. Increase support and facilitate capital access

b. Conducting coaching, counseling and training on marketing activities

c. Improving the condition of supporting infrastructure, such as power grids, telecommunications, highways, clean water, sposses

d. Supporting facilities in the form of means of production 
e. Building local market institutions and marketing systems from production centers to temporary storage, to the distribution of goods to destinations (processors, merchants) and markets as end consumers.

f. Procurement of Regular Seafood Exhibition to promote products and bring together marine farmers and fishermen with investors or permanent buyers.

Businessman

a. Forming local institutions as an association of marketing business actors

b. Involving the public in marketing activities

c. Make innovations related to product packaging in order to attract buyers

Local community

a. Engage in marketing activities

Strategies that can be developed to minimize obstacles to avoid weakness in coastal areas are the construction of community-based industrial facilities and infrastructure with the step taken is to adopt modern fishing gear because, some fishing communities still use traditional tools in the form of hooks, small nets, and traditional nets although the motorization of fishing boats has now been adapted by most fishermen in Muna Regency.

\section{CONCLUSION}

The management of coastal areas is essentially aimed at improving the welfare of the community and has the power to regulate itself in the management of the resources of coastal areas and small islands. The development of coastal areas and small islands requires government support in the form of resource policies, facilities and infrastructure, and legal instruments of resource management. However, to increase economic growth, more detailed mapping is needed to determine the core area and growth center so as to provide a multiplier effect for the development of the surrounding area.

\section{REFERENCES}

[1] K. K. E. Tampi, J. R. T. S. L. Rimper, And V. Warouw. Zooplankton Bioindex In the Waters of Bunaken Island. Journal of Coastal and Tropical Seas. Vol 9 No 1 Pp. 53-43, 2021. Doi: 10.35800/Jplt.9.1.2021.33624.

[2] D. Sitanggang, O. Nainggolan, And J. Sidauruk. Legal Analysis of Criminal Charges Against Perpetrators Who Intentionally Conduct Sand Mining in Coastal Areas and Small Islands Without Permission (Study of Verdict No. 113/Pid.B/2018/Pn. Ffk). Journal of Law Patik, Vol 10 No 1 Pp. 51-60 2021, Doi: 10.51622/Patik.V10i1.222.

[3] R. Ramli, K. Yaqin, And N. Rukminasari. Microplastics Contamination in Green Mussels Perna Viridis In Pangkajene Kepulauan Waters, South Sulawesi, Indonesia. Akuatikisle: J. Aqua. Coast. \& Isle, Vol 5 No 1 Pp. 1-5, 2021, Doi: 10.29239/J.Akuatikisle.5.1.1-5.

[4] J. Malik, D. G. Bengen, And T. Taryono. Small Scale Fisheries Management in coastal waters of Semarang City. Journal of Indonesian Agricultural Sciences. Vol 26 No 2 Pp. 167-176, 2021. 
[5] A. Suryanda, R. Komala, And R. Fahlevi. Coastal Community Perception Relationship About Kkld and Coastal Community Participation in West Lampung KKLD Management. Journal of Environmental Sustainability Management. Vol 4 No 1 Pp. 410-423, 2020, Doi: 10.36813/Jplb.4.1.410-423.

[6] H. Rizaldi, F. Lestari, And S. Susiana. The Level of Damage to The Mangrove Ecosystem in The Sei Jang Estuary Area, Bukit Bestari District, Tanjungpinang City, Riau Islands, Indonesia. Akuatikisle: J. Aqua. Coast. \& Isle. Vol 4 No 2 Pp. 47-51, 2020. Doi: 10.29239/J.Akuatikisle.4.2.47-51.

[7] R. Rivanda, S. Susiana, And D. Kurniawan. Inventory of Clams Tridacnidae In Batu Bilis Island, Kelarik Village Bunguran Utara District, Natuna Regency, Riau Islands, Indonesia. Akuatikisle: J. Aqua. Coast. \& Isle. Vol 4 No 2 Pp. 59-63, 2020. Doi: 10.29239/J.Akuatikisle.4.2.59-63.

[8] M. Miswadi, R. Jhonnerie, And E. Prianto. Land Management Accretion of Pambang Coastal Village, Bengkalis Island, Riau Province. Dynamics of Indonesia's Environment. Vol 7 No 1 Pp. 1-7, 2020. Doi: 10.31258/Dli.7.1. P.1-7.

[9] Y. Mardyani, T. Kurnia, And L. Adrianto. Small Scale Fisheries Management in Coastal Waters of Bangka Regency with Bioeconomics Approach. Journal of Marine and Fisheries Socio-Economic Policy. Vol 10 No 2 Pp. 91-106, 2020. Doi: 10.15578/Jksekp.V10i2.9305.

[10] D. Koemala. Implementation of Investment in The Tourism Sector of Small Islands in South Coastal Regency. Journal of Social Sciences and Education. Vol 4 No 1 Pp. 290301, 2020. Doi: 10.36312/Jisip.V4i1.1053.

[11] M. Khairi. Authority of Provincial Government in Granting Water Management Permits in Coastal Areas and Small Islands. Jatiswara. Vol 35 No 3 Pp. 267-282, 2020. Doi: 10.29303/Jatiswara.V35i3.262.

[12] N. C. Ketti. The Role of Local Wisdom of Papadak in Coastal and Marine Management in Nggodimeda Village and Siomeda Village, Central Rote Subdistrict. Journal of Environmental Sustainability Management Vol 4 No 2 Pp. 513-527, 2020. Doi: 10.36813/Jplb.4.2.513-527.

[13] I. R. G. Kaya, F. De Lima, M. Kaya, And J. M. Matinahoru. Coastal Ecosystem Management of Small Islands for Sustainable Ecotourism on Saparua Island. Makila: Journal of Forestry Research, Vol 14 No 1 Pp. 15-25, 2020. Doi: 10.30598/Makila.V14i1.2503.

[14] Z. Arifin And A. P. Satria. Analisis Kritis Pengelolaan Perairan Pesisir Dan Pulau-Pulau Kecil Di Indonesia (Studi Pengaturan Pengelolaan Perairan Pesisir Dan Pulau-Pulau Kecil Pasca Lahirnya Undang-Undang No 1 Tahun 2014 Dan Undang-Undang No 23 Tahun 2014). Ganec Swara. Vol 14 No 1 Pp. 521-525, 2020. Doi: 10.35327/Gara.V14i1.129.

[15] F. Surur, Z. N. Cahya, And M. S. Wahid. Urgensi Pengembangan Wisata Dalam Perencanaan Wilayah Di Pulau Muna Provinsi Sulawesi Tenggara. Akuatikisle: J. Aqua. Coast. \& Isle. Vol 3 No 2 Pp. 41-47, 2019, Doi: 10.29239/J.Akuatikisle.3.2.41-47.

[16] G. Prajati And S. Widiantoro. Identifikasi Kualitas Air Laut Terkait Pengelolaan Sampah Di Pulau Lengkang Kecil. Jtera (Jurnal Teknologi Rekayasa), Vol 4 No 2 Pp. 203-208. 2019, Doi: 10.31544/Jtera.V4. I2.2019.203-208. 
[17] E. Mustikasari, M. Ramdhan, S. N. Amry, A. Heriati, U. R. Kadarwati, Yulius, J. Prihantono And D. G. Pryambodo. Analysis of Ecological Dimension Characteristics of Small Islands of Nunukan Regency, North Kalimantan. Jurnal Kelautan Nasional. Vol 14 No 1 Pp. 47-57. 2019, Doi: 10.15578/Jkn.V14i1.7458

[18] M. Mosriula. Inventory of Damage to Coastal and Marine Ecosystems in The Kepulauan Riau, Indonesia. Akuatikisle: J. Aqua. Coast. \& Isle. Vol 3 No 1 Pp. 31-39, 2019. Doi: 10.29239/J.Akuatikisle.3.1.31-39.

[19] M. Mosriula. Analysis of Land Suitability, Carrying Capacity, And Development Strategies for Seaweed Cultivation in Labakkang District, Pangkep Regency, Indonesia. Akuatikisle: J. Aqua. Coast. \& Isle. Vol 3 No 2 Pp. 81-90, 2019. Doi: 10.29239/J.Akuatikisle.3.2.81-90.

[20] F. Fendi, L. Lili, A. Rakhfid, And R. Rochmady. The Growth of Seaweed (Eucheuma Cottoni) At Different Fertilizing Doses in The Waters of The Village of Ghonebalano, Duruka District, Muna Regency, Indonesia. Akuatikisle: J. Aqua. Coast. \& Isle. Vol 3 No 1 Pp. 17-22, 2019. Doi: 10.29239/J.Akuatikisle.3.1.17-22.

[21] D. Doman. Kesesuaian Pengaturan Pemanfaatan Zona Migrasi Biota Laut Dalam Peraturan-Peraturan Daerah Provinsi Dengan Uu Tentang Pengelolaan Wilayah Pesisir Dan Pulau-Pulau Kecil (Uu Wp3k). J. Huk.Lingkung. Indonesia. Vol 6 No 1 Pp. 145153, 2019, Doi: 10.38011/Jhli.V6i1.118.

[22] R. Desiani, S. Susiana, And F. Lestari. Utilization Rate of Yellow and Blueback Fusilier (Caesio Teres) At Mapur Waters This Fish Landing in Kelong Village, Bintan Coastal, Bintan Regency, Indonesia. Akuatikisle: J. Aqua. Coast. \& Isle, Vol 3 No 2 Pp. 49-55, 2019. Doi: 10.29239/J.Akuatikisle.3.2.49-55.

[23] M. Chaerul And W. Laksana. Analysis Willingness to Participate from The Marine Coastal Community in Waste Management (Case Study: Pari Island Village, Thousand Islands Regency). Jurnal Presipitasi: Media Komunikasi Dan Pengembangan Teknik Lingkungan. Vol 16 No 3 Pp. 160-171, 2019. Doi: 10.14710/Presipitasi.V16i3.160-171. 